\title{
Validitas PPJB Sebagai Basis PPh Pengalihan Hak atas Tanah dan/atau Bangunan (Tinjauan dari Aspek Hukum Perdata)
}

\author{
Imam Muhasan \\ Politeknik Keuangan Negara STAN \\ Alamat Korespondensi: muhasan.hkn@gmail.com
}

\section{INFORMASI ARTIKEL}

Diterima Pertama

Dinyatakan Diterima

[04122019]

KATA KUNCl:

Pengalihan Hak atas Tanah dan/Atau Bangunan, $P P J B, A J B$.

\section{ABSTRAK}

In the transfer of rights on land and/or buildings transaction, there are at least two types of taxes that can be imposed, namely income tax on the transfer of rights on land and/or buildings (PPhTB) which is imposed on the seller (who transfers the rights) and duty on the transfer of rights on land and/or buildings (BPHTB) which is imposed on the purchaser (who obtains the rights). Unlike BPHTB which is payable when the transfer of rights event is marked by the making of Sale and Purchase Agreement (AJB), PPhTB is payable at the time of Sale and Purchase Binding Agreement (PPJB) making, at which the transfer of rights has not occurred yet. This study aims to examine the validity of PPhTB norm which is based on PPJB (not only $A J B$ ) in PP Number 34 of 2016 against article 4 paragraph (2) of Income Tax Law, according to Civil Law. This research is a doctrinal research using the statutory approach beside the conceptual approach. This research concludes that in civil law perspective, PPJB is not a legal act which causes the transfer of rights on land and/or buildings. As PPJB drafting has generated an income, the income tax may be imposed on it. However, the imposition should not be included in article 4 paragraph (2), but article 4 paragraph (1) Income Tax.

Dalam suatu transaksi pengalihan hak atas Tanah dan/atau Bangunan, setidaknya terdapat dua jenis pajak yang dapat dikenakan, yaitu Pajak Penghasilan atas Pengalihan Hak atas Tanah dan/atau Bangunan (PPhTB) yang dikenakan terhadap Pihak Penjual (yang mengalihkan Hak) dan Bea Perolehan Hak atas Tanah dan atau Bangunan yang dikenakan terhadap pihak Pembeli (yang memperoleh Hak). Berbeda dengan BPHTB yang terutang ketika telah terjadi peristiwa perolehan hak yang ditandai dengan pembuatan Akta Jual-Beli (AJB), PPhTB telah dianggap terutang pada saat dibuatnya Perjanjian Pengikatan Jual-Beli (PPJB), hal mana belum terjadi peralihan hak. Penelitian ini bertujuan untuk menguji kesesuaian norma pengaturan PPh Pengalihan atas Tanah dan/atau Bangunan berbasis PPJB (bukan hanya AJB) dalam PP Nomor 34 Tahun 2016 terhadap Pasal 4 ayat (2) UU PPh, ditinjau dari aspek Hukum Perdata. Penelitian ini merupakan penelitian doktrinal dengan menggunakan pendekatan peraturan perundang-undangan (statute approach), disamping pendekatan konseptual (conceptual approach). Kesimpulan dari penelitian ini adalah bahwa dari sudut pandang hukum perdata PPJB bukanlah perbuatan hukum yang menyebabkan pengalihan hak atas Tanah dan/atau Bangunan. Namun demikian, mengingat dalam PPJB telah timbul adanya suatu penghasilan, maka terhadapnya dapat dikenakan PPh. Namun demikian, pengaturannya tidak dalam Pasal 4 ayat (2), melainkan dalam Pasal 4 ayat (1) UU PPh. 


\section{PENDAHULUAN}

Dalam suatu transaksi pengalihan hak atas Tanah dan/atau Bangunan, setidaknya terdapat dua jenis pajak yang dapat dikenakan, yaitu Pajak Penghasilan Pengalihan Hak atas Tanah dan/atau Bangunan (PPhTB) yang dikenakan terhadap Pihak Penjual (yang mengalihkan Hak) dan Bea Perolehan Hak atas Tanah dan atau Bangunan (BPHTB) yang dikenakan terhadap pihak Pembeli (yang memperoleh Hak). Saat ini, ketentuan tentang pengenaan PPhTB diatur dalam Peraturan Pemerintah Nomor 34 Tahun $2016^{1}$ yang merupakan peraturan pelaksanaan dari Pasal 4 ayat (2) Undang-undang PPh. ${ }^{2}$ Sementara BPHTB diatur dalam Peraturan Daerah pada tiap-tiap Pemerintah Daerah Tingkat II (Kabupaten/Kota), yang merupakan peraturan pelaksanaan dari Undang-Undang Nomor 28 Tahun 2009 tentang Pajak Daerah dan Retribusi Daerah.

Berdasarkan Pasal 2 Peraturan Pemerintah Nomor 34 Tahun 2016, besarnya tarif PPhTB secara umum adalah $2,5 \%$ dari nilai pengalihan hak; $1 \%$ dari nilai pengalihan hak untuk rumah sederhana dan rumah susun sederhana yang dilakukan oleh Wajib Pajak yang usaha pokoknya melakukan pengalihan hak atas tanah dan/atau bangunan; $0 \%$ untuk pengalihan hak kepada Pemerintah, BUMN yang mendapat penugasan khusus dari Pemerintah, atau BUMD yang mendapat penugasan khusus dari Kepala Daerah, sebagaimana dimaksud dalam undang-undang yang mengatur mengenai pengadaan tanah bagi pembangunan untuk kepentingan umum. Sementara untuk BPHTB, Pasal 88 Undang-Undang Nomor 28 Tahun 2009 menyatakan bahwa besaran tarif BPHTB ditetapkan melalui Peraturan Daerah, paling tinggi sebesar 5\% dari Nilai Perolehan Objek Pajak (NPOP).

Berbeda dengan BPHTB yang pengenaan pajaknya baru terutang ketika telah terjadi peristiwa pengalihan hak yang ditandai dengan telah ditandatanganinya Akta Jual Beli (AJB) di depan pejabat berwenang, untuk PPhTB dianggap telah terutang meskipun baru pada tahap Perjanjian Pengikatan Jual Beli (PPJB) beserta perubahannya, selain saat penandatanganan AJB. Berdasarkan Pasal 1 ayat (2) Peraturan Pemerintah Nomor 34 Tahun 2016, PPhTB dikenakan tidak hanya atas penghasilan dari pengalihan hak, tetapi juga atas penghasilan dari PPJB beserta perubahannya. Sebagai peraturan 'induk' yang mendelegasikan pengaturan lebih lanjut dalam Peraturan Pemerintah, Pasal 4 ayat (2) UndangUndang PPh sendiri menyatakan bahwa termasuk jenis penghasilan yang dikenakan PPh secara final adalah penghasilan dari transaksi pengalihan harta berupa tanah dan atau bangunan... dan seterusnya.

\footnotetext{
1 Peraturan Pemerintah Nomor 34 Tahun 2016 tentang Pajak Penghasilan atas Penghasilan dari Pengalihan Hak atas Tanah dan/atau Bangunan, dan Perjanjian Pengikatan Jual Beli atas Tanah dan/atau Bangunan Beserta Perubahannya

2 Undang-Undang Nomor 7 Tahun 1983 tentang Pajak Penghasilan Sebagaimana Telah Diubah dengan Undang-Undang Nomor 36 Tahun 2008
}

Mendasarkan pada ketentuan dalam hukum perdata (KUHPerdata ${ }^{3}$ dan UUPA $^{4}$ beserta peraturan pelaksanaannya), PPJB bukanlah perbuatan hukum yang menandai saat terjadinya pengalihan hak atas tanah dan/atau bangunan. Dalam hukum perdata, pengalihan hak kebendaan antara benda bergerak dan benda tidak bergerak tidaklah sama. Suatu perjanjian yang bermaksud untuk mengalihkan hak milik atas kebendaan tidak dengan begitu saja mengalihkan hak milik atas kebendaan tersebut, tetapi harus disertai dengan penyerahan; adanya perjanjian obligatoir; dan perjanjian kebendaan (zakelijke overeenkomst). ${ }^{5}$ Terkait penyerahan (levering), menurut Pasal 612 KUHPerdata, penyerahan benda bergerak dapat dilakukan dengan penyerahan nyata (feitelijke levering). Dengan sendirinya penyerahan nyata tersebut adalah sekaligus penyerahan yuridis (juridische levering). Sedangkan menurut Pasal 616 KUHPerdata, penyerahan benda tidak bergerak dilakukan melalui pengumuman akta yang bersangkutan dengan cara seperti ditentukan dalam Pasal $620 \quad$ KUHPerdata antara lain membukukannya dalam register. ${ }^{6}$

Dalam pemungutan pajak, penentuan saat terutangnya suatu obyek pajak merupakan salah satu faktor yang sangat esensial. Sebagai contoh, dalam perkara pidana yang melibatkan Gayus HP Tambunan (mantan pegawai Ditjen Pajak) beberapa tahun lalu, ternyata tidak terlepas pula dari adanya kesalahan dalam penentuan saat terutangnya obyek pajak. Terlepas dari perkara korupsi yang didakwakan, Majelis Hakim Pengadilan Negeri Jakarta Selatan menilai bahwa Tim Penelaah Keberatan Pajak yang mengabulkan permohonan keberatan Wajib Pajak (PT SAT) telah 'salah' dalam memahami saat terjadinya pengalihan antiva tetap, dalam hal ini tanah dan/atau bangunan yang menjadi obyek Pajak Pertambahan Nilai sebagaimana diatur dalam Pasal 16D UU PPN. ${ }^{7}$

Keberadaan norma dalam Peraturan Pemerintah Nomor 34 Tahun 2016 yang memasukkan PPJB sebagai obyek PPh, seolah melampaui kewenangan pengaturan yang dimilikinya (ultra vires), mengingat Pasal 4 ayat (2) UU PPh (peraturan perundangundangan yang memberikan kewenangan delegatif kepada Peraturan Pemerintah Nomor 34 Tahun 2016) menyatakan bahwa yang dikenakan PPh secara final adalah penghasilan dari pengalihan harta berupa tanah dan/atau bangunan. Hal mana, secara keperdataan (menurut hukum perdata), PPJB bukanlah perbuatan hukum yang menandai telah terjadinya peralihan hak atas tanah dan/atau bangunan. Oleh karenanya, penelitian ini

\footnotetext{
${ }^{3}$ Burgerlijke Wetboek yang diterjemahkan oleh Prof Subekti dan R Tjitrosudibio sebagai Kitab Undang-Undang Hukum Perdata

${ }^{4}$ Undang-Undang Nomor 5 Tahun 1960 tentang Peraturan Dasar Pokok-Pokok Agraria

5 Herlien Budiono, Kumpulan Tulisan Hukum Perdata di Bidang Kenotariatan: Buku Kesatu, cet. ke-4, Bandung: Citra Aditya Bakti, 2016, hlm. 228.

${ }^{6}$ Frieda Husni Hasbullah, Hukum Kebendaan Perdata: Hak-Hak yang Memberi Kenikmatan, Jakarta: Ind-Hill-Co, 2005, hlm. 45.

7 Putusan Mahkamah Agung Nomor 52 K/Pid.Sus/2013
} 
dimaksudkan untuk menguji validitas materi muatan dalam Peraturan Pemerintah Nomor 34 Tahun 2016 terhadap Pasal 4 ayat (2) UU PPh, terkait pengenaan PPh atas penghasilan dari PPJB, ditinjau dari aspek hukum perdata.

\section{METODE PENELITIAN}

Penelitian ini merupakan penelitian doktrinal atau seringkali disebut penelitian yuridis normatif, dengan menggunakan pendekatan peraturan perundangundangan (statute approach), disamping pendekatan konseptual (conceptual approach). Dalam penelitian ini dilakukan penyandingan (pengujian) atas ketentuan perundang-undangan dibidang perpajakan dengan ketentuan perundang-undangan dibidang hukum perdata terkait Pengalihan Hak atas Tanah dan/atau Bangunan.

\section{HASIL PENELITIAN}

\section{A. PPh atas Pengalihan Hak atas Tanah dan/atau Bangunan}

Berdasarkan Pasal 4 ayat (1) UU PPh, obyek PPh adalah Penghasilan, yaitu setiap tambahan kemampuan ekonomis yang diterima atau diperoleh Wajib Pajak, baik yang berasal dari Indonesia maupun dari luar Indonesia, yang dapat dipakai untuk konsumsi atau untuk menambah kekayaan Wajib Pajak yang bersangkutan, dengan nama dan dalam bentuk apa pun. Dari rumusan pasal tersebut terlihat bahwa dalam memberikan definisi penghasilan, UU PPh menganut pengertian penghasilan dalam arti yang sangat luas, dengan unsur-unsur sebagai berikut:

1) setiap tambahan kemampuan ekonomis

2) yang diterima atau diperoleh Wajib Pajak

3) baik yang berasal dari Indonesia maupun dari luar Indonesia

4) yang dapat dipakai untuk konsumsi atau untuk menambah kekayaan Wajib Pajak yang bersangkutan

5) dengan nama dan dalam bentuk apa pun

Selanjutnya pada Pasal 4 ayat (1) UU PPh mengatur bahwa atas beberapa jenis penghasilan tertentu, pengenaan pajaknya dilakukan secara final. Termasuk dalam penghasilan tertentu yang dikenakan PPh secara final tersebut adalah penghasilan dari transaksi pengalihan harta berupa tanah dan atau bangunan. Sesuai 'perintah' atau kewenangan delegatif dari Pasal 4 ayat (2) UU PPh, saat ini ketentuan mengenai pengenaan PPh atas penghasilan dari transaksi pengalihan hak atas tanah dan/atau bangunan diatur dalam Peraturan Pemerintah Nomor 34 Tahun 2016 yang mencabut Peraturan Pemerintah Nomor 48 Tahun 1994 sebagaimana telah beberapa kali diubah terakhir dengan Peraturan Pemerintah Nomor 71 Tahun 2008 (Perubahan ketiga).
Perbedaan paling mendasar antara Peraturan Pemerintah Nomor 34 Tahun 2016 dengan Peraturan Pemerintah Nomor 48 Tahun 1994 sebagaimana telah bebrapa kali diubah terakhir dengan Peraturan Pemerintah Nomor 71 Tahun 2008 adalah munculnya norma 'baru' atau 'perluasan makna' penghasilan sebagaimana dimaksud dalam Pasal 4 ayat (2) UU PPh, pada Peraturan Pemerintah Nomor 34 Tahun 2016. Bentuk 'perluasan makna' atau 'norma baru' dimaksud adalah ketentuan yang menyatakan bahwa atas Perjanjian Pengikatan Jual Beli atas Tanah dan/atau Bangunan beserta Perubahannya, termasuk dalam kualifikasi obyek pajak yang dikenakan PPh Final. Ketentuan selengkapnya dapat dilihat pada Pasal 1 ayat (1) dan ayat (3) dibawah ini:

\section{Pasal 1 ayat (3):}

Atas penghasilan yang diterima atau diperoleh orang pribadi atau badan dari:

a. pengalihan hak atas tanah dan/atau bangunan;atau

b. perjanjian pengikatan jual beli atas tanah dan/atau bangunan beserta perubahannya, terutang Pajak Penghasilan yang bersifat final.

\section{Pasal 1 ayat (3):}

Penghasilan dari PPJB atas tanah dan/atau bangunan beserta perubahannya sebagaimana dimaksud pada ayat (1) huruf b adalah penghasilan dari:

a. pihak penjual yang namanya tercantum dalam perjanjian pengikatan jual beli pada saat pertama kali ditandatangani; atau

b. pihak pembeli yang namanya tercantum dalam PPJB sebelum terjadinya perubahan atau adendum PPJB, atas terjadinya perubahan pihak pembeli dalam perjanjian pengikatan jual beli tersebut.

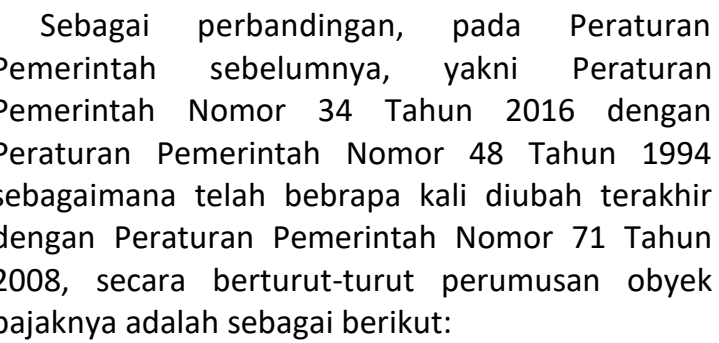

1. PP Nomor 48 Tahun 1994 tentang Pembayaran Pajak Penghasilan atas Penghasilan dari Pengalihan Hak atas Tanah dan/atau Bangunan,

Pasal 1 ayat (1):

Atas penghasilan yang diterima atau diperoleh orang pribadi atau badan dari pengalihan hak atas tanah dan/atau bangunan wajib dibayar Pajak Penghasilan.

Pasal 1 ayat (2):

Pengalihan hak atas tanah dan/atau bangunan sebagaimana dimaksud pada ayat (1) adalah:

a. penjualan, tukar-menukar, perjanjian pemindahan hak, pelepasan hak, penyerahan hak, lelang, hibah, atau cara lain yang 
disepakati dengan pihak lain selain pemerintah;

b. penjualan, tukar-menukar, pelepasan hak, penyerahan hak, atau cara lain yang disepakati dengan pemerintah guna pelaksanaan pembangunan, termasuk pembangunan untuk kepentingan umum yang tidak memerlukan persyaratan khusus;

c. penjualan, tukar-menukar, pelepasan hak, penyerahan hak, atau cara lain kepada pemerintah guna pelaksanaan pembangunan untuk kepentingan umum yang memerlukan persyaratan khusus.

2. PP Nomor 27 Tahun 1996 tentang Perubahan atas Peraturan Pemerintah Nomor 48 Tahun 1994 tentang Pembayaran Pajak Penghasilan atas Penghasilan dari Pengalihan Hak atas Tanah dan/atau Bangunan (tidak ada perubahan, sama dengan rumusan pada PP Nomor 48 Tahun 1994).

3. PP Nomor 79 Tahun 1999 tentang Perubahan Kedua atas Peraturan Pemerintah Nomor 48 Tahun 1994 tentang Pembayaran Pajak Penghasilan atas Penghasilan Pengalihan Hak atas Tanah dan/atau Bangunan (tidak ada perubahan, sama dengan rumusan pada PP Nomor 48 Tahun 1994).

4. PP Nomor 71 Tahun 2008 tentang Perubahan Ketiga atas Peraturan Pemerintah Nomor 48 Tahun 1994 tentang Pembayaran Pajak Penghasilan atas Penghasilan dari Pengalihan Hak atas Tanah dan/atau Bangunan (tidak ada perubahan, sama dengan rumusan pada PP Nomor 48 Tahun 1994).

Adapun besarnya tarif PPh atas penghasilan dari pengalihan hak dan penghasilan dari PPJB beserta perubahannya, menurut Pasal 2 ayat (1) dan ayat (3) Peraturan Pemerintah Nomor 34 Tahun 2016 ditetapkan sebagai berikut:

a. 2,5\% (dua koma lima persen) dari jumlah bruto nilai pengalihan hak atas tanah dan/atau bangunan selain pengalihan hak atas tanah dan/atau bangunan berupa Rumah Sederhana atau Rumah Susun Sederhana yang dilakukan oleh Wajib Pajak yang usaha pokoknya melakukan pengalihan hak atas tanah dan/atau bangunan;

b. $1 \%$ (satu persen) dari jumlah bruto nilai pengalihan hak atas tanah dan/atau bangunan berupa Rumah Sederhana dan Rumah Susun Sederhana yang dilakukan oleh Wajib Pajak yang usaha pokoknya melakukan pengalihan hak atas tanah dan/atau bangunan;atau c. $0 \%$ (nol persen) atas pengalihan hak atas tanah dan/atau bangunan kepada pemerintah, badan usaha milik negara yang mendapat penugasan khusus dari Pemerintah, atau badan usaha milik daerah yang mendapat penugasan khusus dari kepala daerah, sebagaimana dimaksud dalam undang-undang yang mengatur mengenai pengadaan tanah bagi pembangunan untuk kepentingan umum.

Guna meningkatkan efektivitas pemungutan PPh dimaksud, pemerintah melalui Peraturan Pemerintah Nomor 24 Tahun 1997 (vide Pasal Pasal 39 (1) huruf g) menyatakan, bahwa PPAT menolak untuk membuat akta, jika tidak dipenuhi syarat lain atau dilanggar larangan yang ditentukan dalam peraturan perundang-undangan yang bersangkutan. Dalam penjelasannya, pasal ini memberikan contoh syarat dimaksud adalah misalnya larangan untuk membuat Akta, jika kepadanya tidak diserahkan fotokopi Surat Setoran Pajak Penghasilan sebagaimana diatur dalam Peraturan Pemerintah Nomor 48 Tahun 1994 tentang Pembayaran Pajak Penghasilan atas Penghasilan dari Pengalihan Hak atas Tanah dan Bangunan jo. Peraturan Pemerintah Nomor 27 Tahun 1996.

\section{B. Pengalihan Hak Kebendaan dalam Hukum Perdata}

Sumber hukum tentang Benda sebelum tahun 1960 hanyalah yang tertuang di dalam KUHPerdata Buku II tentang Benda, dimulai dari Pasal 499 sampai dengan Pasal 829 KUHPerdata. Sejak Tahun 1960 dengan berlakunya UUPA maka segala aturan yang mengenai bumi, air, dan kekayaan alam yang terkandung di dalamnya yang termuat dalam KUHPerdata dihapuskan kecuali aturan-aturan yang mengenai hipotek. $^{8}$ Berdasarkan Pasal 584 KUHPerdata, cara memperoleh Hak Milik adalah sebagai berikut: ${ }^{9}$

a. Pemilikan (toeegening);

b. Perlekatan atau ikutan (natreking);

c. Daluwarsa atau lewat waktu (verjaring);

d. Warisan (erfopvolging), baik secara ab intestato maupun tertamentair

e. Penyerahan (levering).

Penyerahan merupakan salah satu jenis peralihan hak milik yang paling sering terjadi dalam kehidupan (hukum) di masyarakat. Yang dimaksud dengan penyerahan menurut hukum perdata adalah penyerahan suatu kebendaan oleh pemilik kebendaan tersebut kepada pihak lain dengan tujuan agar pihak lain ini menjadi pemilik dari kebendaan yang diserahkan tersebut. ${ }^{10}$ Menurut sistem hukum perdata (KUHPerdata), suatu perjanjian yang

\footnotetext{
${ }^{8}$ Surini Ahlan Sjarif, Intisari hukum Benda, Jakarta: Galia Indonesia, 1984, hlm 9-10

${ }^{9}$ Op.cit., Herlien Budiono, hlm. 234

10 Ibid., Herlien Budiono, hal 234
} 
bermaksud untuk mengalihkan hak milik atas kebendaan tidak dengan begitu saja mengalihkan hak milik atas kebendaan tersebut, tetapi harus disertai dengan penyerahan; adanya perjanjian obligatoir; dan perjanjian kebendaan (zakelijke overeenkomst).

Perjanjian kebendaan adalah tindakan hukum yang dengan mengindahkan ketentuan undang-undang, timbul karena kesepakatan dari dua pihak atau lebih yang saling mengikatkan diri dengan tujuan menimbulkan, beralih, berubah, atau berakhirnya suatu hak kebendaan. ${ }^{11}$ Urgensi atau pentingnya pembedaan antara benda bergerak dan benda tidak bergerak adalah jika dikaitkan dengan empat hal, yaitu penguasaan, penyerahan, daluwarsa, dan pembebanan. ${ }^{12}$

Menurut KUH Perdata, benda dibedakan menjadi: ${ }^{13}$

a. Benda berwujud (lichamelijke zaken) dan benda tidak berwujud (onlichamelijke zaken) -Pasal 503 KUHPerdata

b. Benda bergerak (roerende zaken) dan benda tidak bergerak (onroerende zaken) - Pasal 504 KUHPerdata

c. Benda yang habis dipakai (verbruikbare zaken) dan benda tidak habis dipakai (onverbruikbare zaken) Pasal 505 KUHPerdata.

Selanjutnya, untuk benda bergerak, dibedakan menjadi dua golongan (Pasal 509-518 KUHPerdata): ${ }^{14}$

a. Benda bergerak karena sifatnya, yaitu benda yang karena sifatnya dapat berpindah atau dipindahkan (Pasal 509 KUHPerdata)

b. Benda bergerak karena ketentuan undang-undang sebagaimana ditetapkan dalam Pasal 511 KUHPerdata, seperti hak yang terbit atas pemakaian dan penggunaan atas benda bergerak, hak atas bunga, hak penuntutan atas uang yang dapat ditagih dan sero atau saham atau andil yang diterbitkan oleh persekutuan perdagangan uang, persekutuan dagang, atau persekutuan perusahaan.

Sementara benda tidak bergerak, dibedakan menjadi tiga golongan: ${ }^{15}$

a. Benda tidak bergerak karena sifatnya, yaitu benda yang karena kodrat benda yang bersangkutan memang tidak bisa dipindahkan, misalnya tanah (Pasal 506 KUHPerdata)

b. Benda tidak bergerak karena peruntukannya atau tujuannya, yaitu benda yang secara kodrati dapat dipindahkan, namun karena oleh pemiliknya dilekatkan pada benda tidak bergerak selaku benda pokok demi suatu tujuan tertentu, maka

\footnotetext{
${ }^{11}$ /bid., Herlien Budiono, hlm. 267.

12 op.cit., Frieda Husni Hasbullah, hlm. 45.

${ }^{13}$ op.cit., Herlien Budiono, hlm. 267.

${ }^{14}$ Ibid., Herlien Budiono, hlm. 228

15 Ibid., Herlien Budiono, hlm. 228
}

benda tersebut kehilangan sifat kemandiriannya sebagai benda bergerak dan berubah menjadi tidak bergerak - Pasal 507 KUHPerdata

c. Benda tidak bergerak karena ketentuan undangundang, yaitu pembuat undang-undang berlandaskan suatu alasan logis menetapkan sesuatu itu adalah termasuk benda tidak bergerak menurut Pasal 508 KUHPerdata.

Kapal yang berukuran lebih dari $20 \mathrm{~m}^{3}$ isi kotor yang terdaftar di setiap syah bandar di seluruh Indonesia, dianggap sebagai kebendaan tidak bergerak - Pasal 314 KUHD.

Adapun ketentuan mengenai penyerahan kebendaan dapat dilihat pada Pasal 612 dan 613 KUHPerdata (untuk benda bergerak) dan Pasal 616 KUHPer (untuk benda tidak bergerak). Menurut Pasal 612 KUHPerdata, penyerahan benda bergerak dapat dilakukan dengan penyerahan nyata (feitelijke levering). Dengan sendirinya penyerahan nyata tersebut adalah sekaligus penyerahan yuridis (juridische levering). Sementara menurut Pasal 616 KUHPerdata, untuk penyerahan benda tidak bergerak, dilakukan melalui pengumuman akta yang bersangkutan dengan cara seperti ditentukan dalam Pasal 620 KUHPer antara lain membukukannya dalam register.

Di bawah ini merupakan beberapa bentuk pengalihan (levering) atas hak kebendaan:

a. Penyerahan benda bergerak yang berwujud dilakukan dengan penyerahan nyata (feitelijke levering), yaitu penyerahan dari tangan ke tangan (Pasal 612 KUHPerdata). Selain itu, dikenal pula:

\section{- Traditio brevi manu}

Penyerahan dimana barang yang akan diserahkan karena sesuatu hal sudah berada dalam penguasaan pihak yang akanmenerima penyerahan, misalnya, penyerahan pada sewabeli.

- Traditio longa manu

Penyerahan dimana barang yang akan diserahkan berada dalam penguasaan pihak ketiga.

\section{- Constitutum possessorium}

Penyerahan dimana benda yang dijual secara faktual oleh karena adanya hubungan hukum baru antara pihak penjual dan pembeli, masih berada di bawah penguasaan pihak penjual, tetapi tidak lagi sebagai pemilik, misalnya, pemberian jaminan fidusia.

b. Penyerahan benda bergerak berupa piutang atas nama dan kebendaan yang tak berwujud lainnya dilakukan dengan jalan memuat akta otentik di bawah tangan (Pasal 613 ayat (1) KUHPerdata). Penyerahan berupa piutang karena surat bawa (aan toonder) dilakukan dengan penyerahan surat itu; penyerahan piutang karena surat-tunjuk (aan order) dilakukan dengan menyerahkan surat 
tagihannya disertai dengan endosemen (Pasal 613 ayat (3) KUHPerdata).

c. Penyerahan benda tidak bergerak harus dilakukan melalui suatu akta yang dibuat di hadapan pejabat yang berwenang (dalam sistem KUHPerdata disebut akte van transport), yang untuk kemudian dicatatkan dan dipublikasikan menurut ketentuan yang berlaku. Khusus untuk pengalihan hak atas tanah dan kebendaan yang melekat di atasnya berlaku ketentuan yang diatur dalam Peraturan Pemerintah Nomor 24 Tahun 1997 tentang Pendaftaran Tanah.

Diantara sekian cara untuk memperoleh hak eigendom, levering yang diatur dalam Pasal 612 sampai dengan Pasal 616 KUHPerdata merupakan salah satu cara yang paling penting. ${ }^{16}$ Levering disebut juga opdracht, overdracht, traditio. Ditinjau dari segi yuridis, yang dimaksud dengan levering adalah pemindahan hak eigendom atas suatu benda yangberasal dari seseorang yang berhak memindahkannya kepada orang lain, yang mengakibatkan orang lain tersebut menjadi pemilik benda yang bersangkutan. ${ }^{17}$

Penyerahan nyata adalah penyerahan dari tangan ke tangan dan yang diserahkan adalah benda-benda bergerak. Pada benda bergerak penyerahan nyata dan penyerahan yuridis jatuh pada waktu yang bersamaan. Sementara pada benda tidak bergerak, penyerahan nyata dan penyerahan yuridis terjadi pada saat yang berlainan atau terpisah, untuk penyerahan yuridis dilakukan melalui pendaftaran tanah yang bersangkutan daalm register umum di hadapan Kepala Seksi Pendaftaran Tanah, dan penyerahan nyata dapat dilakukan secara simbolis misalnya dengan penyerahan kunci rumah yang bersangkutan. ${ }^{18}$

\section{PPJB, AJB dan Pengalihan Hak atas Tanah dan/atau Bangunan}

Salah satu jenis perjanjian yang sering ditemukan dalam penyelenggaraan bisnis properti, yang menunjukkan adanya persetujan antara perusahaan pengembang (developer) properti adalah perjanjian pendahuluan jual beli (atau terkenal dengan singkatan PPJB). ${ }^{19}$ Perjanjian ini dapat disusun bahkan ketika proses pembangunan properti (bisa berupa rumah atau rumah susun atau bagunan gedung) masih berlangsung. PPJB merupakan kesepakatan melakukan jual beli rumah yang masih dalam proses pembangunan antara calon pembeli rumah dengan penyedia rumah yang diketahui oleh pejabat yang berwenang.

\footnotetext{
${ }^{16}$ op.cit., Frieda Husni Hasbullah, h1m.14-115

${ }^{17}$ Ibid., Frieda Husni Hasbullah, hlm. 121

${ }^{18}$ Ibid., Frieda Husni Hasbullah, hlm. 114-115

${ }^{19}$ Andika Wijaya \& Wida Peace Ananta, Hukum Bisnis Properti di Indonesia, Jakarta: Grasindo, 2017, hlm. 249
}

Menurut Pasal 42 ayat (1) UU Nomor 1 Tahun 2011 tentang Perumahan dan Kawasan Perumahan Permukiman, Rumah tunggal, rumah deret, dan/atau rumah susun yang masih dalam tahap proses pembangunan dapat dipasarkan melalui sistem perjanjian pendahuluan jual beli sesuai dengan ketentuan peraturan perundangundangan. Untuk dapat menyusun PPJB, harus memenuhi persyaratan sebagaimana diatur dalam Pasal 42 ayat (2) UU Nomor 11 Tahun 2011, yakni syarat kepastian atas:

a. status pemilikan tanah;

b. hal yang diperjanjikan;

c. kepemilikan izin mendirikan bangunan induk;

d. ketersediaan prasarana, sarana, dan utilitas umum; dan

e. keterbangunan perumahan paling sedikit $20 \%$ (dua puluh persen).

Selanjutnya Pasal 42 ayat (3) UU 11 Tahun 2011 menyatakan bahwa Ketentuan lebih lanjut mengenai sistem perjanjian pendahuluan jual beli akan diatur dalam Peraturan Menteri, dalam hal ini untuk saat ini adalah Menteri PUPR. Berdasarkan Pasal 1 angka 1 Peraturan Menteri PUPR, ${ }^{20}$ Perjanjian Pendahuluan Jual Beli atau Perjanjian Pengikatan Jual Beli yang selanjutnya disebut PPJB adalah kesepakatan antara pelaku pembangunan dan setiap orang untuk melakukan jual beli rumah atau satuan rumah susun yang dapat dilakukan oleh pelaku pembangunan sebelum pembangunan untuk rumah susun atau dalam proses pembangunan untuk rumah tunggal dan rumah deret yang dinyatakan dalam akta notaris.

Pada umumnya suatu PPJB mengandung janji-janji yang harus dipenuhi terlebih dahulu oleh salah satu pihak atau para pihak sebelum dapat dilakukannya perjanjian pokok yang merupakan tujuan akhir dari para pihak. ${ }^{21}$ Persyaratan tersebut dapat bersifat macam-macam. Sebagai contoh, adalah terkait pelunasan harga jual-belinya. Selain itu adanya keadaan dimana penjual yang sertifikat tanah haknya sedang dalam proses balik nama pada kantor Badan Pertanahan Nasional, tetapi penjual bermaksud untuk menjual tanah hak tersebut. Guna mengatasi hal tersebut maka dibuatlah suatu perjanjian pengikatan jual beli sebagai suatu perjanjian pendahuluan untuk sementara menantikan dipenuhinya syarat untuk perjanjian pokoknya, yaitu jual-beli di hadapan PPAT yang berwenang membuatnya. Dengan demikian, PPJB tidak lain adalah perjanjian obligatoir dengan tidak mengurangi, baik unsur-unsur perjanjian, syarat sahnya perjanjian, maupun asas-asas hukum perjanjian.

Peralihan Hak Milik atas tanah diatur dalam Pasal 20 ayat (2) UUPA, Hak milik dapat beralih dan

20 Peraturan Menteri Pekerjaan Umum dan Perumahan Rakyat Nomor 11/PRT/M/2019 tentang Sistem Perjanjian Pendahuluan Jual Beli Rumah

21 Angger Sigit Pramukti, Erdha Widayanto, "Awas" Jangan Beli Tanah Sengketa: Panduan Mengurus Peralihan Hak atas Tanah secara Aman, Cet. Pertama, Yogyakarta: Pustaka Yustisia, 2015, hlm. 50 . 
dialihkan kepada pihak lain. Dua bentuk peralihan Hak Milik atas tanah dapat dijelaskan sebagai berikut: ${ }^{22}$

1. Beralih

Beralih artinya berpindahnya Hak Milik atas tanah dari pemiliknya kepada pihak lain dikarenakan suatu peristiwa hukum. Dengan meninggalnya pemilik tanah, maka Hak Miliknya secara hukum beralih kepada ahli warisnya sepanjang ahli warisnya memenuhi syarat sebagai subyek Hak Milik.

Beralihnya Hak Milik atas tanah yang telah bersertifikat harus didaftarkan ke Kantor Pertanahan Kabupaten/Kota setempat dengan melampirkan surat keterangan kematian pemilik yang dibuat oleh pejabat yang berwenang, surat keterangan sebagai ahli waris yang dibuat oleh pejabat berwenang, bukti identitas ahli waris, sertifikat tanah yang bersangkutan.

\section{Dialihkan/Pemindahan Hak}

Dialihkan/pemindahan hak artinya berpindahnya Hak Milik atas tanah dari pemiliknya kepada pihak lain dikarenakan adanya suatu perbuatan hukum. Contoh perbuatan hukum adalah jual-beli, tukarmenukar, hibah, penyertaan (pemasukan) dalm modal perusahaan, lelang.

Berpindahnya Hak Milik karena dialihkan/pemindahan hak harus dibuktikan dengan akta yang dibuat oleh dan dihadapan Pejabat Pembuat Akta Tanah (PPAT) kecuali lelang dibuktikan dengan Berita Acara Lelang atau Risalah Lelang.

Menurut Pasal 1313 KUH Perdata, ${ }^{23}$ perjanjian adalah suatu perbuatan dimana satu orang atau lebih mengikatkan diri terhadap satu orang lain atau lebih. Adapun perjanjian Jual beli adalah suatu perjanjian bertimbal balik dalam mana pihak yang satu (si penjual) berjanji untuk menyerahkan hak milik atas suatu barang, sedang pihak lainnya (si pembeli) berjanji untuk membayar harga yang terdiri atas sejumlah uang sebagai imbalan dari perolehan hak milik tersebut. ${ }^{24}$ Jual beli merupakan salah satu cara terjadinya peralihan hak atas tanah. Secara umum, jual beli merupakan suatu perbuatan dimana pihak penjual berkewajiban untuk memberikan barang yang menjadi obyek jual beli kepada pihak pembeli dengan menerima sejumlah pembayaran.

Istilah jual-beli tanah dalam peraturan perundangundangan disebutkan dalam ketentuan Pasal 26 Undang-Undang Nomor 5 Tahun 1960 tentang Peraturan Dasar Pokok-Pokok Agraria (UUPA), menyangkut pemindahan hak milik atas tanah. Selain itu, istilah jual-beli juga disebut dalam Pasal 16, Pasal 34, Pasal 54 Peraturan Pemerintah Nomor 40 Tahun 1996 tentang Hak Guna Usaha, Hak Guna Bangunan

\footnotetext{
22 Urip Santoso, Hukum Agraria: Kajian Komprehensif, Jakarta: Kencana, 2012, hlm. 93-94.

${ }^{23}$ Burgerlijke Wetboek yang diterjemahkan oleh Prof Subekti dan R Tjitrosudibio sebagai Kitab Undang-Undang Hukum Perdata

${ }^{24}$ Subekti, Aneka Perjanjian, Bandung: Citra Adithya Bakti, 1995, hlm 1.
}

dan Hak Pakai atas tanah Dari berbagai peraturan perundangan yang menyebutkan istilah jual-beli tersebut, tidak ada yang mendefinisikan secara jelas mengenai pengertian jual beli atas tanah. ${ }^{25}$

Dengan berlakunya UUPA, maka pendaftaran hak atas tanah dan peralihan haknya menurut ketentuan Pasal 19 UUPA beserta peraturan pelaksananya. Untuk perjanjian jual beli properti (baik tanah, rumah, rumah susun atau bangunan gedung) dilakukan melalui akta jual beli. Perjanjian jual beli properti hanya dapat dilakukan apabila properti sudah selesai dibangun atau sudah siap untuk dijual (untuk tanah), serta telah memenuhi syarat-syarat yang ditentukan oleh perundang-undangan.

Menurut Pasal 19 UUPA, akhir kegiatan pendaftaran tanah yang diadakan oleh pemerintah adalah pemberian surat tanda bukti hak, yang berlaku sebagai alat pembuktian yang kuat. UUPA tidak menyebut nama surat tanda bukti hak atas tanah yang didaftar. Baru pada Pasal 13 ayat (3) Peraturan Pemerintah Nomor 10 Tahun 1961 dinyatakan bahwa surat tanda bukti hak atas tanah yang didaftarkan dinamakan sertifikat, yaitu salinan buku tanah dan surat ukur setelah dijahit menjadi satu bersama-sama dengan suatu kertas sampul yang bentuknya ditetapkan Menteri Agraria.

Pasal 3 Peraturan Pemerintah Nomor 24 Tahun 1997, salah satu tujuan pendaftaran tanah adalah untuk memberikan kepastian hukum dan perlindungan hukum kepada pemegang hak atas suatu bidang tanah, satuan rumah susun dan hak-hak lain yang terdaftar agar dengan mudah dapat membuktikan dirinya sebagai pemegang hak yang bersangkutan. Untuk memberikan kepastian hukum dan perlindungan hukum, kepada pemegang hak yang bersangkutan diberikan sertifikat hak atas tanah. ${ }^{26}$

Berdasarkan Pasal 37 ayat 1 Peraturan Pemerintah Nomor 24 Tahun 1997, peralihan hak atas tanah dan hak milik atas satuan rumah susun melalui jual beli, tukar menukar, hibah, pemasukan dalam perusahaan dan perbuatan hukum pemindahan hak lainnya, kecuali pemindahan hak melalui lelang, hanya dapat didaftarkan, jika dibuktikan dengan akta yang dibuat oleh PPAT yang berwenang menurut ketentuan peraturan perundang-undangan yang berlaku. Akta ini lazim disebut Akta Jual Beli (AJB). Dengan demikian, suatu transaksi pengalihan hak atas tanah dan/atau bangunan dianggap telah terjadi saat dibuatnya AJB, bukan PPJB.

\section{PPh atas Penghasilan dari PPJB vs AJB}

Sebagaimana telah diuraikan pada poin A, B dan C bab Hasil Penelitian dan Pembahasan di atas, UU PPh melalui Pasal 4 ayat (2) telah menetapkan bahwa atas penghasilan dari transaksi pengalihan harta berupa tanah dan/atau bangunan dikenakan PPh bersifat final. Sejatinya, 'masuknya' jenis penghasilan ini

\footnotetext{
${ }^{25}$ Op.cit., Angger Sigit Pramukti, Erdha Widayanto, hlm. 50

${ }^{26}$ Op.cit., Urip Santoso, hlm. 315
} 
(pengalihan hak atas tanah dan/atau bangunan) ke dalam pasal 4 ayat (2) UU PPh, baru muncul pada UU Nomor 10 Tahun 1994 (perubahan kedua atas UU Nomor 7 Tahun 1983 tentang Pajak Penghasilan), hingga seterusnya, dalam UU Nomor 17 Tahun 2000 (perubahan ketiga), dan UU Nomor 36 Tahun 2008 (perubahan keempat). Pada UU Nomor 7 Tahun 1983 dan UU Nomor 7 Tahun 1991 (perubahan pertama), Pasal 4 ayat (2) belum atau tidak 'memasukkan' jenis penghasilan ini dalam kelompok penghasilan yang dikenakan PPh final, yang artinya masuk dalam jenis penghasilan yang dikenakan PPh secara umum sebagaimana diatur dalam Pasal 4 ayat (1) UU PPh.

Sebagai petunjuk pelaksanaan atas Pasal 4 ayat (2) pada tiap-tiap Undang-undang PPh di atas, telah beberapa kali diterbitkan Peraturan Pemerintah. Mulai dari Peraturan Pemerintah Nomor 48 Tahun 1994, Peraturan Pemerintah Nomor 27 Tahun 1996 (perubahan pertama), Peraturan Pemerintah Nomor 79 Tahun 1999 (perubahan kedua) maupun Peraturan Pemerintah Nomor 71 Tahun 2008 (perubahan ketiga), hingga yang terakhir Peraturan Pemerintah Nomor 34 Tahun 2016, yang sekaligus juga mencabut dan menggantikan peraturan pemerintah sebelumnya.

Jika dalam Peraturan Pemerintah Nomor 48 Tahun 1994 hingga perubahan terakhir yakni Peraturan Pemerintah Nomor 71 Tahun 2008 sama sekali tidak menyinggung tentang PPJB, Peraturan Pemerintah Nomor 34 Tahun 2016 secara eksplisit dan 'tegas' menyatakan bahwa yang menjadi obyek PPh final bukan hanya penghasilan dari transaksi pengalihan hak, tetapi juga atas penghasilan dari PPJB. Hal mana tidak ada perubahan penormaan dalam Pasal 4 ayat (2) UU PPh dari semenjak UU Nomor 10 Tahun 1994 hingga UU Nomor 36 Tahun 2008.

Dari sudut pandang hukum perdata, ketentuan dalam Peraturan Pemerintah Nomor 34 Tahun 2016 yang menyatakan penghasilan dari PPJB sebagai obyek PPh final, tidaklah tepat. Hal ini mengingat bahwa secara keperdataan, tanah dan/atau bangunan termasuk dalam kualifikasi benda tak bergerak, yang oleh karenanya saat terjadinya pengalihan hak bukanlah saat ditandatanganinya PPJB, melainkan saat dibuatnya AJB. Pengaturan tentang pengenaan penghasilan dari PPJB sebagai objek PPh final, dapat dipandang pencantuman 'norma baru' diluar materi muatan yang pengaturannya didelegasikan oleh Pasal 4 ayat (2) UU PPh. Namun demikian, mengingat dalam pembuatan PPJB terdapat potensi timbulnya penghasilan, maka atas penghasilan dimaksud merupakan PPh, sebagaimana dapat dijumpai rumusan dalam Pasal 4 ayat (1) UU PPh.

Pada dasarnya PPh dikenakan pendekatan ability to pay dan benefit principle. Sebelum tahun 1984, Ordonansi Pajak Perseroan 1925 atas laba perseroan dan Ordonansi Pajak Pendapatan 1944 atas pendapatan orang pribadi mendefinisikan obyek pajak dengan mendasarkan pada source \& periodecity concept, dimana untuk pemajakan perseroan, laba terbatas pada yang bersumber dari modal yang ditanamkan baik dalam maupun di luar perusahaan; sedangkan untuk pemajakan pendapatan terbatas yang berasal dari 4 sumber yang mengalir secara berkala dari usaha dan tenaga, harta gerak, harta tak gerak dan pembayaran berkala. ${ }^{27}$

Source \& periodecity concept tersebut muncul bersamaan dengan teori Irving Fischer tentang income (penghasilan) sebagai flow of services/yield, menurunkan teori tree \& fruit (penghasilan hanya buahnya saja) dan hen \& egg (penghasilan terbatas telurnya saja). Sebelum itu, Adam Smith merumuskan penghasilan secara makro sebagai penjumlahan dari penghasilan setiap warga masyarakat. Sedangkan Robert J Hicks menawarkan well-offness concept (penghasilan sebagai nilai maksimum yang dapat dikonsumsi tanpa mengurangi kekayaan dan kekayaan mengarah pada yang riil sehingga ada teori capital maintenance concept). ${ }^{28}$

\section{PENUTUP}

\section{A. Kesimpulan}

Dalam praktik, pembuatan PPJB sebagai suatu perjanjian pendahuluan dalam transaksi pengalihan hak atas tanah dan/atau bangunan merupakan suatu kelaziman. Memperhatikan bahwa atas pembuatan PPJB berpotensi melahirkan suatu penghasilan, maka terhadapnya dapat dikenakan PPh. Namun demikian, pengenaan penghasilan atas PPJB dengan PPh final melalui Peraturan Pemerintah Nomor 34 Tahun 2016 bukanlah langkah yang tepat, mengingat Pasal 4 ayat (2) UU PPh (sebagai peraturan 'induk' dari Peraturan Pemerintah Nomor 34 Tahun 2016), menyatakan bahwa yang menjadi obyek PPh final adalah penghasilan dari pengalihan harta berupa tanah dan/atau bangunan. Hal mana secara keperdataan, PPJB bukanlah merupakan perbuatan hukum yang menandai telah terjadinya pengalihan hak atas tanah dan/atau bangunan. Adapun atas penghasilan dari PPJB, dapat dikenakan PPh secara umum sebagaimana diatur dalam Pasal 4 ayat (1) UU PPh.

\section{B. Saran}

Pengaturan tentang jenis penghasilan tertentu dalam kualifikasi yang dikenakan PPh secara final sebagaimana dalam Pasal 4 ayat (2) UU PPh, termasuk penghasilan dari PPJB, sesungguhnya masih dalam ranah open legal policy. Namun demikian, dalam merumuskan norma hendaknya senantiasa memperhatikan pula ketentuan dalam bidang hukum lainnya, termasuk hukum perdata. Adapun ketentuan dalam Peraturan Pemerintah Nomor 34 Tahun 2016 yang mengenakan PPh atas penghasilan dari PPJB akan tetap sejalan (sesuai dengan kedudukannya sebagai peraturan pelaksanaan) dengan Pasal 4 (2) UU PPh, jika bunyi objek pajak dalam Pasal 4 ayat (2) diubah menjadi: “...atas penghasilan terkait (atau yang

\footnotetext{
${ }^{27}$ Gunadi, Panduan Komprehensif Pajak Penghasilan, Jakarta: Bee Media Indonesia, 2013, hlm. 57.

28 Ibid., Gunadi, hlm. 17
} 
berkaitan) dengan transaksi pengalihan harta berupa tanah dan/atau bangunan...dst".

\section{DAFTAR PUSTAKA (REFERENCES)}

\section{Buku:}

Andika Wijaya, Wida Peace Ananta, Hukum Bisnis Properti di Indonesia, Jakarta: Grasindo, 2017

Angger Sigit Pramukti, Erdha Widayanto. "Awas" Jangan Beli Tanah Sengketa: Panduan Mengurus Peralihan Hak atas Tanah secara Aman, Cet. Pertama, (Yogyakarta: Pustaka Yustisia, 2015

Frieda Husni Hasbullah. Hukum Kebendaan Perdata: Hak-Hak yang Memberi Kenikmatan, Jakarta: IndHill-Co, 2005

Herlien Budiono. Kumpulan Tulisan Hukum Perdata di Bidang Kenotariatan: Buku Kesatu, cet. ke-4, Bandung: Citra Aditya Bakti, 2016

Gunadi. Panduan Komprehensif Pajak Penghasilan, Jakarta: Bee Media Indonesia, 2013

Subekti. Aneka Perjanjian, Cet. ke-10, Bandung: Citra Adithya Bakti

Sunindhia, Ninik Widiyanti. Pembaharuan Hukum Agraria, Jakarta: Bina Aksara, 1988

Surini Ahlan Sjarif, Intisari hukum Benda, Jakarta: Galia Indonesia, 1984

Urip Santoso. Hukum Agraria: Kajian Komprehensif, Jakarta: Kencana, 2012

\section{Peraturan Perundang-Undangan:}

Undang-Undang Nomor 7 Tahun 1983 tentang Pajak Penghasilan Sebagaimana Telah Diubah dengan Undang-Undang Nomor 36 Tahun 2008

Peraturan Pemerintah Nomor 34 Tahun 2016 tentang Pajak Penghasilan atas Penghasilan dari Pengalihan Hak atas Tanah dan/atau Bangunan, dan Perjanjian Pengikatan Jual Beli atas Tanah dan/atau Bangunan Beserta Perubahannya

Burgerlijke Wetboek yang diterjemahkan oleh Prof Subekti dan R Tjitrosudibio sebagai Kitab UndangUndang Hukum Perdata

Undang-Undang Nomor 5 Tahun 1960 tentang Peraturan Dasar Pokok-Pokok Agraria

Undang-Undang Nomor 1 Tahun 2011 tentang Perumahan dan Kawasan Perumahan Permukiman

Peraturan Pemerintah Nomor 24 Tahun 1997 tentang Pendaftaran Tanah

Peraturan Menteri Pekerjaan Umum dan Perumahan Rakyat Nomor 11/PRT/M/2019 tentang Sistem Perjanjian Pendahuluan Jual Beli Rumah

\section{Putusan Pengadilan:}

